\title{
PENGARUH PENERAPAN STRATEGI PQ4R MENGGUNAKAN MEDIA FLIP BOOK TERHADAP HASIL BELAJAR IPS SISWA KELAS V SD DI ERA PANDEMI
}

\author{
Lilis Sumaryani ${ }^{1}$, Rusijono ${ }^{2}$, Suhanadji ${ }^{3}$ \\ ${ }^{1}$ Universitas Negeri Surabaya \\ Email: lilis.19057@mhs.unesa.ac.id \\ ${ }^{2}$ Universitas Negeri Surabaya \\ Email: rusijono@unesa.ac.id \\ ${ }^{3}$ Universitas Negeri Surabaya \\ Email: suhanadii@unesa.ac.id
}

\begin{abstract}
Abstrak
Penelitian ini bertujuan menerapkan strategi PQ4R dengan media flip book IPS terhadap siswa kelas 5 SDN Geluran 1 dalam pembelajaran daring. Hal ini dilakukan dalam rangka meningkatkan hasil belajar siswa selama pembelajaran melalui daring yang kurang interaktif akibat pandemi Covid-19. Metode penelitian ini menggunakan pretest-posttest control group design. Hasil penelitian ini adalah sebagai berikut: (1) Aktivitas pembelajaran dengan penerapan strategi PQ4R melalui media flip book terdapat dua aktivitas yaitu aktivitas guru diperoleh hasil sebesar $86,25 \%$ dapat dikategorikan baik sekali dan untuk aktivitas siswa diperoleh sebesar $84 \%$ dengan kategori baik sekali. (2) Respon siswa terhadap penerapan strategi PQ4R melalui media flip book terhadap hasil belajar IPS di kelas $\mathrm{V}$ terdapat pesentase sebesar $73 \%$ dapat dikategorikan baik. (3) Penerapan strategi PQ4R melalui media flip book terhadap hasil belajar IPS pada kelas 5 pada sampel sejenis, yakni kelompok eksperimen terdapat $t_{\text {hitung }}>t_{\text {tabel }}$ atau 33,609 $>1,708$. Sedangkan hasil belajar dengan data beda jenis, yaitu kelompok eksperimen dan kelompok kontrol memperoleh $t_{\text {hitung }}$ sebesar 2,262 dan $t_{\text {tabel }}$ sebesar 2,000, maka $t_{\text {hitung }}>t_{\text {tabel. }}$. Dengan kata lain, Ha diterima dan Ho ditolak. Dengan demikian dapat disimpulkan bahwa penerapan PQ4R menggunakan media flip book sangat berpengaruh baik terhadap hasil belajar mata pelajaran IPS siswa kelas 5 SDN Geluran 1 Kecamatan Taman Kabupaten Sidoarjo.
\end{abstract}

Kata kunci : Media Flip Book, Strategi PQ4R, Hasil Belajar, dan Pembelajaran Daring

\section{Abstract}

This research aims to apply the PQ4R strategy with social studies flip book media to 5th grade students of SDN Geluran 1 in online learning. This is done in order to improve student learning outcomes during online learning that is less interactive due to the Covid-19 pandemic. This research method uses pretestposttest control group design. The results of this study are as follows: (1) Learning activities with the application of PQ4R strategy through flip book media, there are two activities, namely teacher activities, the results of which are $86.25 \%$ can be categorized as very good and for student activities, $84 \%$ are obtained in the very good category. (2) Student responses to the implementation of the PQ4R strategy through flip book media on social studies learning outcomes in class $V$, there is a percentage of $73 \%$ which can be categorized as good. (3) The application of the $P Q 4 R$ strategy through flip book media on social studies learning outcomes in grade 5 in a similar sample, namely the experimental group there is $t_{\text {hitung }}>t_{\text {tabel }}$ or $33,609>1,708$. While the learning outcomes with different types of data, namely the experimental group and the control group obtained $t_{\text {hitung }}$ of 2,262 and $t_{\text {tabel }}$ of 2,000 , then $t_{\text {hitung }}>t_{\text {tabel. }}$ In other words, $\mathrm{Ha}$ is accepted and Ho is rejected. Thus, it can be concluded that the application of PQ4R using flip book media has a very good effect on learning outcomes for social studies subjects for grade 5 students at SDN Geluran 1, Taman Subdistrict, Sidoarjo Regency.

Keyword : Flip Book Media, PQ4R Strategy, Learning Outcomes, and Online Learning 


\section{PENDAHULUAN}

Salah satu upaya meningkatkan keberhasilan pembelajaran adalah dengan strategi pembelajaran. Penerapan strategi pembelajaran yang tepat akan menghasilkan peserta didik yang cerdas. Namun, saat ini dunia sedang dilanda pandemi Covid-19. Akibatnya, proses pembelajaran juga mengalami perubahan drastis, yakni dari luring ke daring. Baik guru maupun peserta didik dipaksa menyesuaikan dengan keadaan ini. Melalui aplikasi Zoom Meeting, Google Meet, dan aplikasi sejenis lainnya, proses pembelajaran dilaksanakan di rumah masing-masing. Hal ini mengakibatkan sulitnya memperoleh hasil pembelajaran yang efektif, khususnya pada siswa Sekolah Dasar. Untuk itu, pemilihan strategi pembelajaran menjadi penting demi mendukung kesuksesan proses pembelajaran.

Apalagi dalam masa pandemi Covid-19 ini, pembelajaran membaca materi, seperti materi IPS (IImu Pengetahuan Sosial), memiliki keterbatasan, khususnya dari pemilihan media baca yang menarik supaya peserta didik tertarik dengan bahan bacaan materi IPS. Selama pembelajaran melaui daring, peserta didik kelas 5 di SDN Geluran 1 Kecamatan Taman kurang maksimal dalam menggunakan buku materi IPS. Hal ini dikarenakan turunnya antusiasme membaca buku paket konvensional. Dengan kata lain, bukan saja strategi pembelajaran yang diperlukan demi suksesnya proses pembelajaran daring, melainkan juga media pembelajaran yang tepat dan menarik. Hal ini sejalan dengan apa yang diuatarakan Sobon (2019: 98) bahwa bangkitnya keinginan, minat, motivasi dan rangsangan dari dalam diri siswa yang menimbulkan kegiatan belajar guna mencapai tujuan.

Melihat fakta tersebut, penelitian ini terlebih dahulu berupaya menentukan model pembelajaran yang tepat untuk diterapkan kepada siswa kelas 5 SDN Geluran 1. Dalam menentukan model pembelajaran yang tepat harus dipertimbangkan dan diperhatikan bagaimana kondisi peserta didik, media, materi bahan ajar, dan kondisi pendidiknya.

Dengan

mempertimbangkan aspek-aspek tersebut, pembelajaran kooperatif (cooperatif learning) diterapkan, yakni pembelajaran bersama dalam kelompok kecil untuk saling membantu sehingga meningkatkan penalaran, daya hafal dan meminimalisir ketergantungan pada guru. Hal ini sejalan dengan kurikulum 2013 yang telah diterapkan dalam pembelajaran Sekolah Dasar. 
Salah satu metode yang atas yang secara luring, kegiatan mendukung pembelajaran kooperatif pembelajaran di penelitian ini adalah strategi PQ4R (preview, question, dilaksanakan melalui daring dengan read, reflect, recite, dan review), yang aplikasi Google Meet dan menggunakan mana memberikan pengalaman awal media flip book. Penelitian ini dilakukan pada peserta didik untuk membaca. pada siswa kelas 5 di SDN Geluran 1 Metode ini menghendaki peserta didik Kecamatan Taman, Kabupaten Sidoarjo. untuk memamami isi bacaan atau teks, menemukan ide-ide pokok bacaan serta dapat membuat pertanyaan sesuai isi bacaan. Hal serupa juga disampaikan Aisha, dkk (2019) dalam jurnalnya yang berjudul "Penerapan Strategi PQ4R dalam meningkatkan keterampilan membaca pemahaman siswa kelas 5 SD”, yang menggambarkan tentang kesulitan peserta didik dalam memahami bacaan. Setelah peneliti menerapkan strategi PQ4R dalam proses pembelajarnnya, didapatkan hasil bahwa peserta didik kelas 5 SDN Cobong Bandung mengalami kenaikan signifikan pada hasil belajarnya. Karena dalam proses pembelajaran, ketrampilan membaca merupakan tonggak utama yang harus ditekankan, khususnya bagi peserta didik yang berada pada jenjang sekolah dasar.

Berdasarkan permasalahan di atas, penelitian ini berupaya menerapkan Strategi pembelajaran PQ4R dan media pembelajaran Flip Book dalam mata pelajaran IPS. Berbeda dengan penelitian yang dilakukan Aisha dkk di

\section{METODE PENELITIAN}

Penelitian ini berupaya mendapatkan hasil pembelajaran yang memuaskan dalam mata pelajaran IPS selama pembelajaran daring. Karena itu, strategi PQ4R dan media flip book diterapkan untuk mencari adakah pengaruhnya bagi hasil pembelajaran IPS kelas 5 SD. Untuk itu, penelitian ini menggunakan metode penelitian PretestPosttest Control Group Design. Ini adalah suatu desain di mana terdapat dua kelompok yang dipilih secara random, kemudian diberi pre-test untuk mengetahui keadaan awal (Sugiyono, 2017: 112-113), hal ini akan dapat diketahui secara rinci atau akurat, karena dapat membandingkan dengan diadakan sebelum diberi perlakuan melalui posttest. Perlakuan dalam hal ini adalah penerapan strategi PQ4R dengan media flip book.

Instrumen penelitian yang digunakan adalah lembar observasi pembelajaran guru dan siswa, lembar angket respon peserta didik, soal pre- 
test dan post-test, silabus, rencana pelaksanaan pembelajaran (RPP), dan lembar penilaian hasil belajar. Teknik pengumpulan data dalam penelitian ini dilakukan dengan observasi dan teknik tes.

Prosedur dan analisis data penelitian, yakni pertama memisahkan kelas 5 di SDN Geluran 1 menjadi dua kelompok, yakni kelompok eksperimen dan kelompok kontrol yang masingmasing berjumlah 26 siswa. Kegiatan pembelajaran dilaksanakan sebanyak empat pertemuan, dengan kelompok eksperimen diterapkan strategi PQ4R menggunakan media flip book, sementara kelompok kontrol dengan pembelajaran konvensional. Pertemuan pertama, kedua kelompok diberikan pretest. Kemudian, pertemuan kedua dan ketiga dilaksanakan pembelajaran, setelah itu pertemuan terakhir dilakukan post-test.

Selama dua pertemuan di kelas eksperimen yang menerapkan strategi PQ4R dan media flip book diteliti aktivitas pembelajarannya untuk menjawab rumusan masalah pertama, dan setelah ini siswa diminta mengisi angket respon peserta didik untuk menjawab rumusan masalah kedua. Sementara untuk menjawab rumusan masalah ketiga tentang adakah pengaruh penerapan strategi $P Q 4 R$ dan media flip book dalam pembelajaran IPS di kelas 5 SD Geluran 1 Sidoarjo dilakukan uji t sampel sejenis pada kelas eksperimen dan uji t sampel berbeda jenis.

\section{HASIL DAN PEMBAHASAN}

Penelitian ini bertujuan mengetahui pengaruh dari penerapan strategi PQ4R dan media flip book pelajaran IPS pada kelas 5 Sekolah Dasar secara daring dengan aplikasi video conference Google Meet. Namun, pertama analisis dimulai dari observasi pembelajaran dan respon peserta didik di kelas eksperimen pada saat menerapkan strategi PQ4R menggunakan media flip book. Adapun hasil penelitian ini diterangkan sebagai berikut :

\section{A. Aktivitas Pembelajaran}

Dalam observasi aktivitas pembelajaran ditemukan bahwa aktitivas guru selama pembelajaran daring dengan menerapkan strategi PQ4R dan media flip book pelajaran IPS pada kelas 5 SDN Geluran 1 Sidoarjo memperoleh hasil sebesar 86,25\%. Hal ini dihitung dari jumlah perolehan indikator sebesar 207, kemudian dibagi jumlah maksimum 240 dan dikali $100 \%$. Sehingga hasil yang diperoleh adalah $86,25 \%$. 


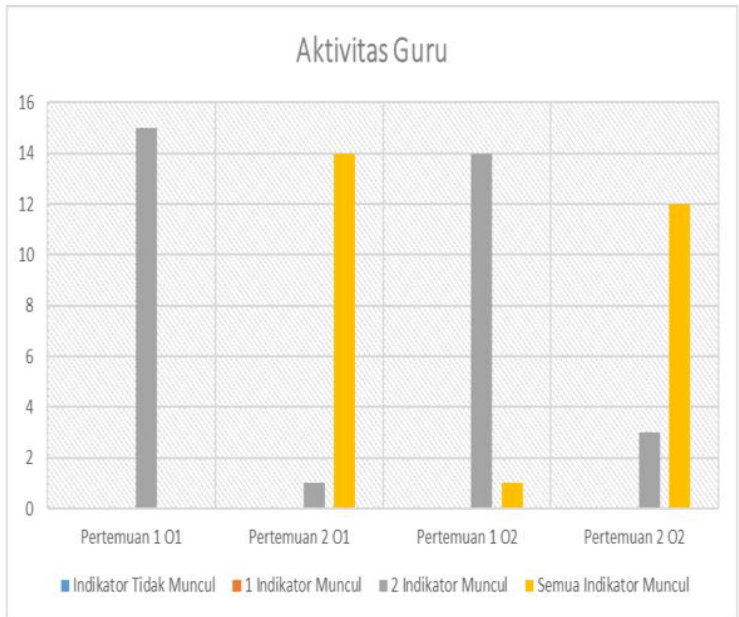

Grafik 1. Aktivitas Guru

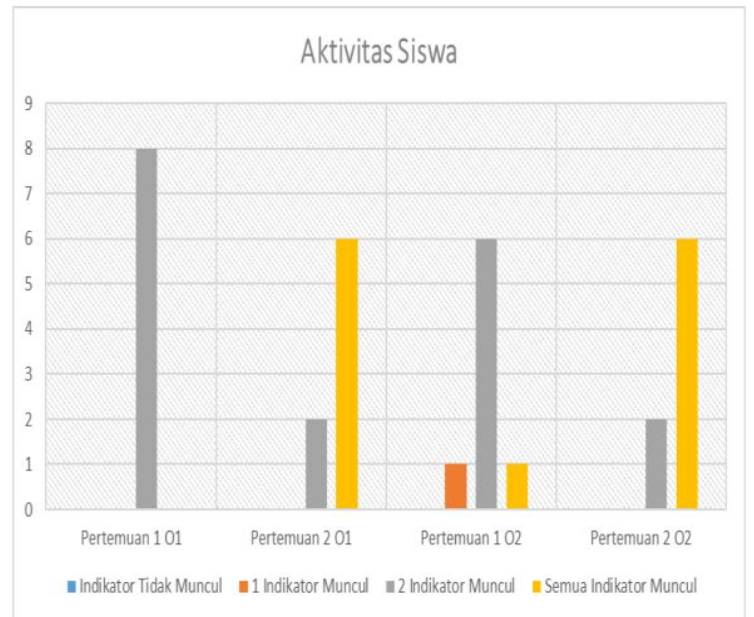

Grafik 2. Aktivitas Siswa

Berdasarkan grafik 1.1 di atas Menurut grafik 1.2 di atas diketahui tampak bahwa obervasi dilakukan oleh 2 pengamat (observer) dalam dua pertemuan yang menerapkan strategi PQ4R dan media flip book. Dengan hasil sebesar 86,25 \%, maka aktivitas guru dapat dikategorikan sebagai 'baik sekali'.

Sementara observasi terhadap aktivitas siswa ditemukan bahwa selama pembelajaran daring dengan menerapkan strategi PQ4R dan media flip book pelajaran IPS pada kelas 5 SDN Geluran 1 Sidoarjo memperoleh hasil sebesar 84,4 \%. Perolehan ini didapat dari membagi jumlah perolehan indikator sebesar 108 dengan jumlah maksimum yang daapat diperoleh 128, kemudian dikali $100 \%$. Untuk itu, hasil yang diperoleh adalah 84,4\%.

bahwa observasi yang dilakukan oleh 2 pengamat dalam dua pertemuan memperoleh hasil sebesar 84,4\%. Dengan kata lain, aktivitas siswa dapat dikategorikan sebagai 'baik sekali'.

\section{B. Respon Peserta Didik}

Penghitungan respon peserta didik melalui lembar angket yang diisi 26 siswa kelas 5 SD Geluran 1 yang dijadikan kelompok eksperimen setelah pembelajaran secara daring dengan strategi PQ4R dan media flip book diterapkan. Penghitungan ini berkaitan dengan minat siswa kelas 5 SDN Geluran 1 terhadap adanya penerapan pembelajaran baru dengan strategi PQ4R dan media flip book mata pelajaran IPS. Indikator yang dipakai dalam angket tersebut adalah tertarik, semangat, senang, kecewa, sikap dan keinginan. 
Tabel 1: respon peserta didik terhadap penerapan strategi PQ4R menggunakan media flip book

\begin{tabular}{lccccc}
\hline \multirow{2}{*}{ Indikator } & Item & $\begin{array}{c}\text { Hasil } \\
\text { Skor }\end{array}$ & $\begin{array}{c}\text { Skor } \\
\text { Tertinggi }\end{array}$ & Presentase & Kategori \\
\hline \multirow{2}{*}{ Tertarik } & 1 & 116 & 130 & $89 \%$ & Sangat Baik \\
\cline { 2 - 6 } & 2 & 115 & 130 & $88 \%$ & Sangat Baik \\
\hline \multirow{2}{*}{ Semangat } & 5 & 115 & 130 & $88 \%$ & Baik \\
\cline { 2 - 6 } & 13 & 114 & 130 & $88 \%$ & Baik \\
\hline \multirow{2}{*}{ Senang } & 6 & 103 & 130 & $79 \%$ & Baik \\
\cline { 2 - 6 } & 7 & 107 & 130 & $82 \%$ & Sangat Baik \\
\hline \multirow{3}{*}{ Kecewa } & 3 & 50 & 130 & $38 \%$ & Cukup \\
\cline { 2 - 6 } & 4 & 55 & 130 & $42 \%$ & Cukup \\
\cline { 2 - 6 } & 8 & 57 & 130 & $44 \%$ & Baik \\
\hline \multirow{2}{*}{ Sikap } & 9 & 102 & 130 & $78 \%$ & Baik \\
\cline { 2 - 6 } & 10 & 108 & 130 & $83 \%$ & Baik \\
\cline { 2 - 6 } & 12 & 97 & 130 & $75 \%$ & Baik \\
\hline Keinginan & 11 & 100 & 130 & $77 \%$ & Baik \\
\hline \multirow{2}{*}{ Prosentase Keseluruhan } & & $73 \%$ & Baik \\
\hline & & & & &
\end{tabular}

Pada hasil tabel angket 1 respon terdapat presentase sebesar $73 \%$ atau peserta didik terhadap penerapan dapat dikategorikan 'baik'. strategi PQ4R menggunakan media flip C. Pengaruh Penerapan Strategi book terhadap hasil belajar IPS di kelas PQ4R Melalui Media Flip Book 5 Sekolah Dasar Negeri Geluran 1 Untuk menghitung pengaruh Taman Sidoarjo dengan hasil pembagianpenerapan pembelajaran daring dengan angket respon yang terdapat 6 indikatorstrategi PQ4R dan media flip book, adapun yaitu tertarik, semangat, senang,yang dihitung adalah uji t sampel sejenis kecewa, sikap, dan keinginan yang(kelompok eksperimen) dan uji t sampel 
beda jenis (kelompok eksperimen danbook. Hasil data normalitas pada kelompok kontrol).

penelitian ini akan di jelaskan melalui

Sebelum itu perlu adanya uji program Statistical Package for Social normalitas. Uji normalitas didapatkan Sciencefor windows release (SPSS). dari data pre-test dan post-test hasil Adapun hasil uji normalitas adalah pembelajaran IPS dengan penerapan sebagai berikut:

strategi PQ4R menggunakan media flip

Tabel 2: Uji Normalitas (Kolmogorov-Smirnov)

\begin{tabular}{llccc}
\hline & Data & Sig. & $\alpha$ & Keterangan \\
\hline Kelompok Ekperimen & PRE_TEST & 0,172 & 0,05 & Normal \\
\cline { 2 - 5 } Kelas V B & POST_TEST & 0,074 & 0,05 & Normal \\
\hline \multirow{2}{*}{$\begin{array}{l}\text { Kelompok Kontrol Kelas } \\
\text { V }\end{array}$} & PRE_TEST & 0,054 & 0,05 & Normal \\
\cline { 2 - 5 } & POST_TEST & 0,068 & 0,05 & Normal \\
\hline
\end{tabular}

Berdasarkan tabel 2 uji normalitas didapat dari nilai sig sebesar 0,068, pada kelompok eksperimen di atas, maka 0,068 >0,05.

dapat dikatakan bahwa terdapat sig

Setelah uji normalitas dilakukan sebesar 0,172; maka sig > 0,05 atau uji homogenitas. Hasil uji homogenitas $0,172>0,05$. Sehingga dapat adalah sebagai berikut:

disimpulkan data untuk pre-test berdistribusi normal. Sementara, untuk post-test didapatkan hasil sig sebesar 0,074 maka sig > 0,05 atau 0,074 > 0,05 . Dengan demikian data post-test dapat disimpulkan berdistribusi nromal.

Sedangkan hasil penghitungan data normalitas di pre-test kelompok kontrol didapatkan nilai sig sebesar 0,054, maka sig > 0,05 atau 0,054 > 0,05 . Untuk itu dapat disimpulkan hasil pre-test berdistribusi normal. Hal yang sama juga berdistribusi normal pada data post-test kelompok kontrol. Hal ini 
Tabel 3: Uji Homogenitas

\begin{tabular}{lccc}
\multicolumn{1}{r}{ Data } & Sig & a & Keterangan \\
\hline Pre-test & 0,803 & 0,05 & Homogen \\
\hline Post-Test & 0,929 & 0,05 & Homogen \\
\hline
\end{tabular}

Berdasarkan tabel 3 uji $\quad$ Tahap selanjutnya uji $t$ sampel homogenitas di atas diketahui data sejenis kelompok eksperimen penelitian homogen. Hal ini didapatkan menggunakan SPSS. Adapun data yang dari nilai sig yang melebihi a $(0,05)$, diuji adalah hasil data pre-test dan postsehingga kedua data baik pre-test test.

maupun pst-test dikatakan homogen.

Tabel 4: Uji t-test sampel sejenis

\begin{tabular}{lcccc}
\hline Data & thitung $_{\text {tabel }}$ & Sig & A \\
\hline $\begin{array}{l}\text { Pre-Test dan Post-Test } \\
\text { Kelompok eksperimen }\end{array}$ & 33,609 & 1,708 & 0,000 & 0,05 \\
\hline
\end{tabular}

Merumuskan Hipotesis Statistik

Ho $: \mu=0$, Tidak terdapat pengaruh penerapan strategi PQ4R menggunakan media flip book terhadap hasil belajaran IPS di kelas 5 B Sekolah Dasar

$\mathrm{Ha}: \mu=0$, Ada pengaruh penerapan strategi PQ4R menggunakan media flip book terhadap hasil belajaran IPS di kelas 5 B Sekolah Dasar.

Kriteria pengujian:

Ho ditolak dan Ha diterima, jika

$$
t_{\text {hitung }}>t_{\text {tabel }}
$$

Ho diterima dan Ha ditolak jika $t_{\text {hitung }}<t_{\text {tabel }}$

Dari hasil tabel 1.5 diperoleh hasil uji t berupa thitung sebesar 33,609 $>t_{\text {tabel }}$ sebesar 1,708, maka Ha diterima dan Ho ditolak. Artinya, terdapat pengaruh signifikan.

Sedangkan uji t sampel berbeda jenis (kelompok eksperimen dan kelompok kontrol) didapatkan hasil sebagai berikut : 
Tabel 5: Uji t-test sampel berbeda

\begin{tabular}{lcccc}
\hline Data & $t_{\text {hitung }}$ & $t_{\text {tabel }}$ & Sig & A \\
\hline $\begin{array}{l}\text { Pre_Test } \\
\text { Kelompok ekperimen dan kontrol }\end{array}$ & 1,855 & 2,000 & 0,070 & 0,05 \\
\hline $\begin{array}{l}\text { Post_Test } \\
\text { Kelompok Ekperimen dan kontrol }\end{array}$ & 2,262 & 2,000 & 0,028 & 0,05 \\
\hline
\end{tabular}

Berdasarkan tabel 1.6 hasil uji $\mathrm{t}$ terhadap kelas 5 SDN Geluran sampel berbeda diperoleh data pre-test Kecamatan Taman Kabupaten Sidoarjo kelompok eksperimen dan kelompok adalah media flip book IPS sebagaimana kontrol adalah thitung sebesar 1,855 dan gambar berikut:

$t_{\text {tabel }}$ sebesar 2,000, maka $t_{\text {hitung }}<t_{\text {tabel. }}$. Dengan demikian, Ho diterima dan $\mathrm{Ha}$ ditolak, yang artinya tidak ada perbedaan pre-test kedua kelompok tersebut.

Sementara uji t sampel berbeda dari data post-test kelompok eksperimen dan kelompok kontrol didapatkan $t_{\text {hitung }}$ sebesar 2,262 dan $t_{\text {tabel }}$ sebesar 2,000, maka $t_{\text {hitung }}>t_{\text {tabel }}$. Dengan kata lain, $\mathrm{Ha}$ diterima dan Ho ditolak. Hal ini menandakan bahwa ada pengaruh posttest kelompok eksperimen dan kelompok kontrol dari hasil pemebelajaran IPS kelas 5 SDN Geluran 1 Sidoarjo.

\section{Pembahasan}

Dari hasil analisis di atas secara lebih ringkas dapat diuraikan dalam pembahasan. Adapun media pembelajaran secara daring menggunakan aplikasi google meet dengan menerapkan strategi PQ4R

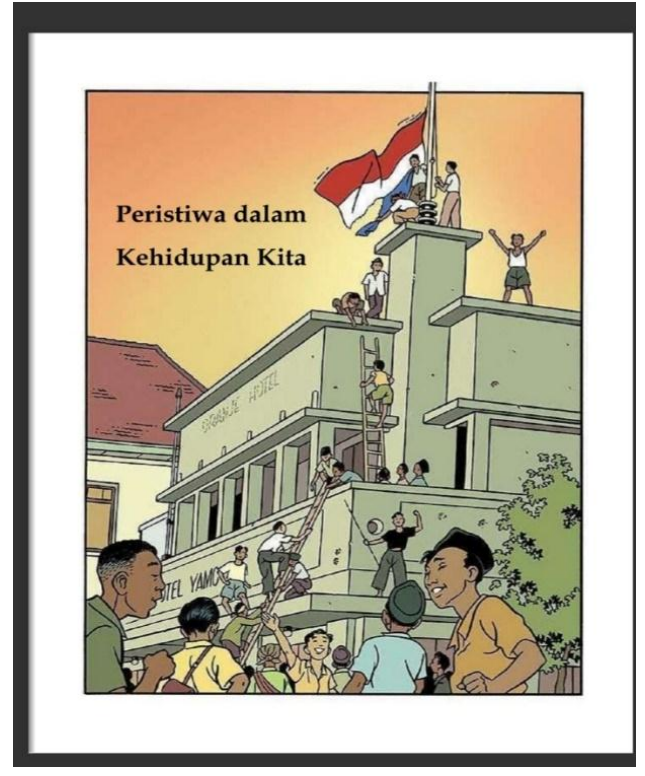

Gambar 1.1 Cover Depan Media Flip Book

Sampul depan media flip book IPS yang digunakan sebagaimana gambar 1.1 di atas. Sementara tampak materi media flip book sebagai berikut: 


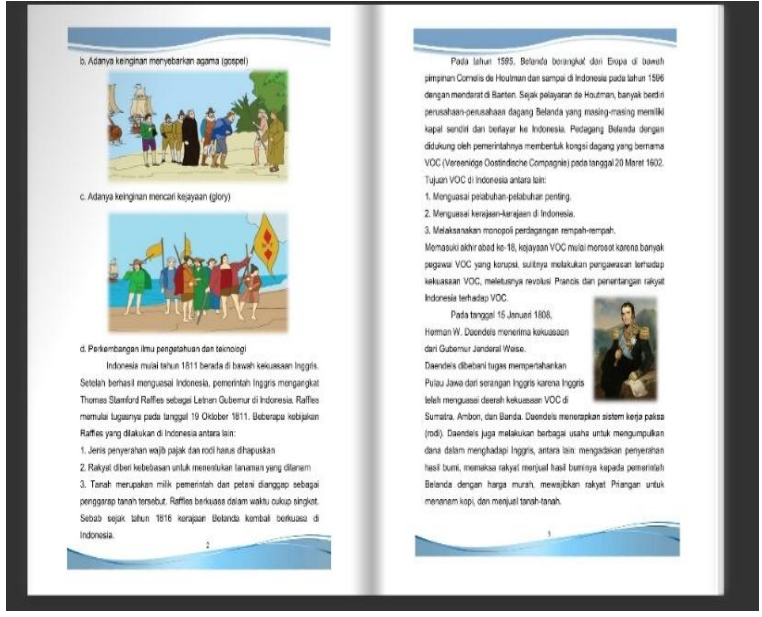

Gambar 1.2

Bagian Materi Media Flip Book

Gambar 1.2 memperlihatkan bagian dalam media flip book IPS yang digunakan dalam penelitian ini. Sedangkan pembahasan tentang penelitian ini secara ringkas dijelaskan di bawah ini.

\section{A. Aktivitas Pembelajaran}

Pembelajaran strategi PQ4R menggunakan media flip book terhadap hasil belajar IPS pada kelas 5 Sekolah Dasar Negeri Geluran 1 Kecamatan Taman Sidoarjo. Media pembelajaran sangat dibutuhkan dalam setiap pelaksanaan yang diterapkan pada peserta didik. Aktivitas pembelajaran terdapat dua observasi guru dan siswa. Penelitian ini juga membuktikan teori konstruktivis yang mana, pendidik memberikan tangga bagi peserta didik untuk meningkatkan pengetahuannya, tetapi peserta didik sendirilah yang harus memanjat tangga tersebut.
Hasil aktivitas guru dalam penelitian ini yang dilakukan selama pembelajaran dengan penerapan strategi PQ4R menggunakan media flip book terhadap hasil belajar IPS pada kelas 5 Sekolah Dasar Negeri Geluran 1 Kecamatan Taman Sidoarjo memperoleh hasil sebesar $86,25 \%$, maka dapat dikategorikan baik sekali. Oleh karena itu, pendidik harus mempertahankan dan meningkatkan aktivitasnya terutama dalam memberi motivasi siswa, membimbing siswa untuk dapat memahami materi, menggunakan bahasa yang baik dan benar, dan mengevaluasi dalam pembelajaran.

Hasil observasi aktivitas siswa maka dapat dilihat pada 8 aspek yang diukur dalam proses kesiapan perserta didik dalam mengikuti pembelajaran daring di masa pandemik melalui arahan yang diberikan oleh pendidik yaitu antusiasme siswa saat apersepsi, perhatian siswa terhadap guru pada saat penyampaian materi, keaktiva siswa dalam bertanya, keaktifan siswa dalam menjawab pertanyaan, interaksi siswa saat melakukan diskusi secara berkelompok, keaktifan siswa dalam membaca teks bacaan, keberanian dan keaktivan siswa dalam mengemukakan pendapatnya, dan kemampuan siswa dalam menggunakan media dengan baik 
dan benar. Maka hasil dari 8 indikator yang terdapat pada hasil observasi siswa sebesar $84,4 \%$ dengan kata lain dapat disimpulkan bahwa mendapatkan deskripsi baik sekali.

\section{B. Respon Peserta Didik}

Penelitian Wahyuningsih (2012) yang berjudul "Pengembangan Media Komik Bergambar Materi Sistem Saraf untuk pembelajaran yang menggunakan strategi PQ4R" menunjukkan hasil respon peserta didik, bahwa penggabungan materi pempelajaran menggunakan strategi PQ4R dengan media komik bergambar ini membuat peserta didik memiliki kreatif dan berpikir kritis. Belajar dengan minat akan mendorong peserta didik untuk berpartisipasi dalam pembelajaran dengan kata lain ada minat untuk belajar (Suardika, 2021: 12). Minat peserta didik muncul jika mendapatkan stimulus yang di butuhkan atau yang dipelajari mempunyai arti atau bermakna pada diri peserta didik. Pembelajaran menggunakan media komik pada strategi PQ4R menyebabkan peserta didik merasa senang, suka, dan menumbuhkan sikap positif berupa perhatian yang mendalam. Hasil mnat siswa dalam perenrapan strategi PQ4R menunjukkan presentase sebesar $75 \%$, maka dapat dikatakan strategi PQ4R sangat membantu siswa menemukan makna tulisan dan informasi darik apa yang dibaca.

Dalam penelitian ini juga dalam garis teori konstruktivisme di mana prinsipnya adalah siswa mampu menyusun atau membangun pengetahuannya sendiri ketika dirinya berusaha untuk mengorganisasikan pengalaman barunya berdasarkan pada kerangka kognitif yang sudah ada dalam pikirannya (Cahyanto, 2019: 275). Dengan kata lain, pengetahuan seseorang merupakan konstruksi (bentukan) dari dirinya (Saguni, 2019: 22). Di dalam situasi dan kondisi tertentu, dalam hal ini pembelajaran, siswa dapat mengkonstruksi pemahamannya sendiri dan pendidik bertindak sebagai fasilitator yang membantu terbentuknya pengetahuan siswa. Dari dasar penjelasan di atas, teori konstruktivisme merupakan sebuah teori yang memiliki sifat membangun, baik dari segi kemampuan, pemahaman di dalam proses pembelajaran. Karena dengan memiliki sifat membangun maka keaktifan peserta didik dapat diharapkan sehingga akan meningkat kecerdasannya. Peserta didik dapat mencari sendiri permasalahannya, membuat pengetahuannya sendiri melalui kekuatan berpikir. 
Hasil analisis terhadap angket respon peserta didik menunjukkan bahwa peserta didik menjadi lebih mudah dalam memahami materi yang diberikan melalui buku elektronik flip book. Respon peserta didik terhadap penerapan strategi PQ4R melalui media flip book terhadap hasil belajar IPS di kelas 5 Sekolah Dasar Negeri Geluran 1 Taman Sidoarjo dengan hasil pembagian angket respon yang terdapat 6 indikator yaitu tertarik, semangat, senang, kecewa, sikap, dan keinginan yang terdapat prosentase sebesar $73 \%$ atau dapat dikategorikan baik.

\section{Pengaruh Penerapan Strategi PQ4R Melalui Media Flip-Book}

Pada penelitian yang dilakukan Pratama, at.al. (2014) yang berjudul tentang Pengaruh Penerapan Pembelajaran PQ4R Konstektual Terhadap Hasil Belajar IPS dan Sikap Peduli Lingkungan Siswa Kelas V SD Gugus I Gianyar temuan ini menunjukkan bahwa model pembelajaran yang diterapkan dalam proses pembelajaran IPS yakni pembe-lajaran PQ4R kontekstual berpengaruh secara signifikan terhadap hasil pem-belajaran IPS dan siskap peduli lingkungan pada siswa kelas 5 SD gugus I Gianyar. Menurut pendapat Lasmawan (2010) bahwa model pembelajaran yang digunakan oleh guru berpengaruh terhadap kualitas proses belajar mengajar yang dilakukan yang pada hasil akhirnya berdampak pada hasil belajar siswa.

\section{Melalui} pembelajaran menggunakan startegi $P Q 4 R$ ini siswa dirangsang untuk lebih aktif melakukan kegiatan membaca, maka apa yang didapat peserta didik merupakan hasil temuanya sendiri. Dengan kata lain siswa aktif mencari tahu bukan diberi tahu, sehingga siswa akan lebih berhatihati dalam membaca bahan bacaan. Dengan pembelajaran PQ4R kontekstual, suasana pembelajaran tidak lagi kaku atau membosankan melainkan lebih menarik peserta didik untuk belajar. Penelitian ini juga membuktikan sesuai dengan teori Vygotsky yaitu anak-anak-anak memperoleh pengetahuan dan keterampilan melalui interaksi sosialnya (Titin, dkk, 2021). Sejalan dengan teori tersebut, dalam pembelajaran kontekstual memperhatikan asas masyarakat belajar. Pembelajaran ini lebih berfokus pada kerjasama tim dengan orang lain, teman sejawat antar kelompok yang mempunyai pengalaman membagi pengetahuan dan keterampilan pada oleh orang lain sehingga selama proses pembelajaran dapat lebih bermakna bagi siswa, yaitu belajar yang mengutamakan proses daripada produk (Azizah, 2018: 
47-48). Hal tersebut turut berpengaruh pada hasil belajar, yang diperkuat oleh temuan Santosa (2013) yang menunjukkan bahwa prestasi belajar peserta didik yang mengikuti pembelajran berlangsung. Selain itu, pembelajaran PQ4R kontekstual secara versamaan juga berpengaruh terhadap sikap peduli lingkungan. hal tersebut berpijak pada pandangan bahwa, siswa akan lebih mudah belajar apabila hal-hal yang dikerjakan adalah yang dengan kehidupan mereka seperti lingkungan sekitar.

Pada hasil yang dilakukan peneliti di kelas 5 SDN geluran 1 Taman Sidoarjo yang menggunakan penerapan pembe-lajaran strategi PQ4R melalui media flip book terhadap hasil belajar pada materi IPS yaitu menggunakan tes awal pada pertemuan pertama yaitu dengan lembar soal tes yang diberikan kepada peserta didik melalui google form pada pertemuan pertama. Untuk pertemuan kedua dan pertemuan ketiga yaitu pembelajaran penerapan pembelajaran strategi PQ4R melalui media flip book terhadap hasil belajar pada materi IPS melalui google meet pada materi tentang tokoh-tokoh pahlawan Indonesia dalam mempertahankan kedaulatannya. Untuk pertemuan ke empat yaitu melakukan post test dengan menggunakan google form.

Pada uji $\mathrm{t}$ test sampel sejenis menggunakan dua cara untuk mengetahui hasil pada kelas $5 \mathrm{~B}$ yang berjumlah 26 siswa dengan penerapan strategi PQ4R melalui media flip book terhadap hasil belajaran IPS di kelas 5 B Sekolah Dasar. Untuk mengetahui uji pertama meng-gunakan uji $t$ yaitu terdapat $t_{\text {hitung }}$ sebesar 33,609 dan $t_{\text {tabel }}$ sebesar 1,708 maka $t_{\text {hitung }}>t_{\text {tabel }}$ atau 33,609 > 1,708 maka Ha diterima dan Ho ditolak. Cara kedua yaitu melihat signifikan apabila tingkat signifikan di bawah 0,05, maka dapat disimpulkan tedapat pengaruh yang signifikan. Hasil dari penghitungan dengan cara ke dua yaitu terdapat signifikan hitung sebesar 0,000 atau sig $<0,05$, maka $0,000<$ 0,05. Dapat disimpulkan Ha diterima dan Ho ditolak. Jadi dapat disimpulkan terdapat pengaruh penerapan strategi PQ4R menggunakan media flip book terhadap hasil belajaran IPS di kelas 5 B Sekolah Dasar di masa pandemik.

Pada penelitian ini menggunakan dua kelompok yaitu kelompok eksperimen yang menggunakan pembelajaran strategi PQ4R menggunakan media flip book dan kelokpok kontrol menggunakan pembe-lajaran secara konvensional. Hasil kedua kelompok dilakukan menggunakan uji t-test sampel 
berbeda dengan pengitungan data PreTest Kelompok eksperimen dan kelompok kontrol terdapat $t_{\text {hitung }}$ sebesar 1,855 dan $t_{\text {tabel }}$ sebesar 2,000, maka dapat disimpulkan $\mathrm{t}_{\text {hitung }}<\mathrm{t}_{\text {tabel }}$ atau 1,855 $<2,000$. Jadi Ho diterima dan Ha ditolak, maka Pre-Test kelompok ekperimen dan kelompok kontrol tidak ada perbedaan terhadap hasil pembelajaran IPS pada kelas 5 Sekolah Dasar. Untuk data Post_Test kelompok kkperimen dan kelompok kontrol terdapat $t_{\text {hitung }}$ sebesar 2,262 dan $t_{\text {tabel }}$ sebesar 2,000, maka dapat disimpulkan $t_{\text {hitung }}>t_{\text {tabel }}$ atau 2,262 $>2,000$. Jadi Ha diterima dan Ho ditolak, maka Post_Test kelompok ekperimen dan kelompok kontrol ada perbedaan terhadap hasil pembelajaran IPS pada kelas 5 Sekolah Dasar.

\section{KESIMPULAN}

Dari hasil penelitian dapat disimpulkan bahwa hasil observasi terhadap aktivitas pembelajaran guru dan siswa dalam menerapkan strategi PQ4R dan media flip book diperoleh presentase sebesar $86,25 \%$ bagi guru yang dapat dikategorikan 'baik sekali' dan presentase sebesar $84 \%$ dengan kategori 'baik sekali' dalam aktivitas siswa.
Hasil respon peserta didik dalam penerapan strategi PQ4R dan media flip book ini mendapatkan presentase sebesar $73 \%$ yang dapat dikategorikan 'baik'. Hal ini tampak dari antusiasme siswa selama penerapan strategi dan media tersebut.

Sementara hasil analisis pengaruh penerapan strategi PQ4R dan media flip book IPS terhadap hasil belajar siswa kelas 5 SDN Geluran 1 Sidoarjo untuk uji $t$ sampel sejenis memperoleh $t_{\text {hitung }}$ sebesar 33,609 dan $t_{\text {tabel }}$ sebesar 1,708 maka $t_{\text {hitung }}>t_{\text {tabel }}$ atau 33,609 > 1,708. Jadi, Ha diterima dan Ho ditolak yang artinya terdapat pengaruh dari penerapan strategi PQ4R dan media flip book. Untuk uji t sampel berbeda dengan data post-test kelompok eksperimen dan kelompok kontrol didapatkan $t_{\text {hitung }}$ sebesar 2,262 dan $t_{\text {tabel }}$ sebesar 2,000, maka $t_{\text {hitung }}>t_{\text {tabel }}$. Dengan kata lain, Ha diterima dan Ho ditolak. Dengan demikian dapat disimpulkan bahwa penerapan PQ4R menggunakan media flip book sangat berpengaruh baik terhadap hasil belajar mata pelajaran IPS siswa kelas 5 SDN Geluran 1 Kecamatan Taman Kabupaten Sidoarjo. 


\section{DAFTAR PUSTAKA}

Aisha, A.A. N., Hendriani, A., \& Heryanto, D. (2019). Penerapan Strategi PQ4R dalam meningkatkan keterampilan membaca pemahaman siswa kelas 5 SD. Jurnal Pendidikan Guru Sekolah Dasar, 4(1), 329-229 https://doi.org/10.17509/jpgsd.v4i1.20676

Azizah, Lilik F. (2018). Pengaruh Penerapan Metode Pembelajaran Snowball Throwing Terhadap Peningkatan Prestasi Belajar Matematika Siswa Tunarungu Ditinjau dari Efikasi Diri Akademik. Jurnal Autentik: Jurnal Pengembangan Pendidikan Dasar, 2(1), 46-56.

Cahyanto, I D., \& Prabawati, M N. (2019). Konstruktivisme dalam Pembelajaran Matematika. Prosiding: Seminar Nasional \& Call For Papers. Universitas Siliwangi: Program Studi Magister Pendidikan Matematika.

Lasmawan. (2010). Menelisik Pendidikan IPS dalam Perspektif Kontekstual-Empiris. Singaraja: Mediakom Indonesia Press Bali.

Pratama, K A B. Lasmawan, I W \& Marhaeni, I N. (2014). Pengaruh Penerapan Pembelajaran PQ4R Kontekstual Terhadap Hasil Belajar IPS dan Sikap Peduli Lingkungan Siswa Kelas V SD Gugus I Gianyar. E-Journal Program Pascasarjana Universitas Pendidikan Ganesha, 4(1), 1-11.

Saguni, Fatimah. (2019). Penerapan Teori Konstruktivis dalam Pembelajaran. Jurnal Paedagogia, 8(2), 19-32.

Santosa, S., Mardiyana, M., \& Sutrima (2013). Eksperimentasi Pembelajaran Kooperatif Tipe Team Assisted Individualization (TAI) dengan Pendekatan Contextual Teaching and Learning ditinjau dari Keaktifan Belajar Peserta Didik SMP Negeri di Kabupaten Karanganyar Tahun Pelajaran 2012/2013. Jurnal Pembelajaran Matematika, 1(5), 435-445.

Sobon, K., Mangundap., J M., \& Walewangko, S. (2019). Pengaruh Penggunaan Smartphone Terhadap Motivasi Belajar Siswa Sekolah Dasar di Kecamatan Mapacet Kota Manado. Jurnal Autentik: Jurnal Pengembangan Pendidikan Dasar, 3(2), 97-106.

Suardika, I K., Heni., \& Anse, L. (2021). Penerapan Model Pembelajaran Project Based Learning (PjBL) untuk Meningkatkan Hasil Belajar Siswa Sekolah Dasar. Jurnal Autentik: Jurnal Pengembangan Pendidikan Dasar, 5(1), 1020.

Sugiyono. (2017). Metode Penelitian Pendidikan Pendekatan Kuantitatif, Kualitatif dan $R \& D$. Bandung: Alfa Beta.

Titin., Sunarno, W., \& Masykuri, M. (2012). Pembelajaran Biologi Menggunakan Model Sains Teknologi Masyarakat (STM) Berbasis Proyek untuk Meningkatkan Hasil Belajar dan Sikap Peduli Lingkungan. E-Journal Inkuiri Program Pascasarjana Universitas Sebelas Maret, 1(3), 245-257.

Wahyuningsih, A. N. (2012). Pengembangan Media Komik Bergambar Materi Sistem Saraf untuk Pembelajaran yang Menggunakan Strategi PQ4R. Journal of Innovative Science Education, 1(1), 102-110. 